\title{
Bringing Art Market Organizations to China: Cross-Border Isomorphism, Institutional Work and its Unintended Consequences
}

\author{
Svetlana Kharchenkova*
}

\begin{abstract}
This study proposes a new explanation for institutional differences of organizations in China. It focuses on how two organizational forms dominant in contemporary art markets - commercial galleries and auction houses - were first established in China in the 1990s. Based on archival and interview data, it argues that the organizational forms were introduced to China due to mimetic isomorphism, and that their divergences from the foreign models are the result of unintended consequences of institutional work. It highlights the role of individual agency, including the role of foreign nationals, in organization-building in China. The findings also have implications for institutional theory: the article shows how the political, cultural and institutional context in China shaped institutional work that needed to be conducted and led to unintended consequences of institutional work.
\end{abstract}

Keywords: economic sociology; mimetic isomorphism; institutional work; organization-building; art market; gallery; auction; contemporary art; China

Studies of China's economic transition have focused on issues such as the role of the state in developing market capitalism, the influence of market reforms on state power and bureaucracy, the impact of markets on societal inequality, and the beneficiaries of market reform. ${ }^{1}$ Research of the mechanisms of China's institutional change during market transition has primarily concentrated on the transformation of pre-existing institutional structures, whereas mechanisms of importation and transformation of new models remain under-researched. ${ }^{2}$ I address this gap by focusing on the importation of the organizational forms of commercial galleries and auction houses that dominate contemporary art markets internationally and in present-day China. This article studies where the models first came from, who implemented them in China, and how. It pays particular

* University of Amsterdam and Leiden University. Email: s.s.kharchenkova@hum.leidenuniv.nl.

1 Nee 1989; Nee and Opper 2012; Oi 1995; for overviews, see Fligstein 1996; Szelenyi and Kostello 1996.

2 Oi 1995; Walder 1995. 
attention to the divergences of Chinese organizations from the original models and to the political, cultural and institutional context of contemporary art in China during the 1990s.

In order to understand the microprocesses of importation of organizational models of galleries and auction houses to China and their transformation, I argue that the concept of institutional work, and an institutional perspective in sociology more broadly, are productive. Although a body of empirical research of institutional work is emerging, to my knowledge, this concept has not been applied to the empirical material of China. ${ }^{3}$ This approach makes us rethink the origins of institutional differences during the economic transition in China. Scholars of China and post-socialist countries in Eastern Europe explained differences in their economic organizational arrangements by a combination of new and pre-existing structures, which they conceptualized as "hybrid forms,"4 "bricolage,"5 and "recombinant properties,"6 emphasizing path dependence and the lingering influence of the socialist institutional order. ${ }^{7}$ In contrast, this article looks at institutional work - at micromechanisms by which new organizational forms were introduced and implemented. As a result, it offers an alternative explanation for organizational differences. In particular, I argue that some differences between organizations in China and abroad are not grounded in a combination of new and pre-existing structures, ${ }^{8}$ but are an unintended outcome of institutional work in an unstructured environment. Another advantage of this approach is that it highlights the role of individual agency in institution building in China.

The argument unfolds as follows. After introducing the conceptual framework, I provide an overview of the local environment to which the models were imported. Then I show who conducted the institutional work of implementing these models and why. Next I discuss what institutional work was conducted, and how it was shaped by the local political, cultural and institutional context. Finally, I show that differences in organizations stem from the unintended consequences of institutional work in an unstructured environment.

\section{Institutional Perspective}

To understand how the organizational models of commercial galleries and auction houses were introduced in China and their transformation, we need a combination of concepts in institutional literature. Like some other studies of the emergence of capitalist institutions in China, ${ }^{9}$ this article relies on institutional theory, which addresses how and why institutions and practices are copied and

3 For an overview, see Lawrence, Leca and Zilber 2013.

4 Nee 1992.

5 Stark and Bruszt 1998.

6 Stark 1996.

7 Pieke 2016; Stark 1992; Walder 1995.

8 Lawrence and Suddaby 2006; Stark and Bruszt 1998

9 Guthrie 1999. 
established. It underscores the idea that institutions are built by local historical and cultural processes, rather than universal laws. Institutional sociologists emphasize cultural and symbolic dimensions, such as ritual, meanings, myth and ceremony, rejecting rational choice and functionality as reasons for organizational diffusion. ${ }^{10}$

To explain why the two models were brought to China, I rely on the concept of isomorphism, which is used in sociological institutional literature to explain homogenous structural features within organizational fields. This perspective posits that organizations imitate others not because it makes them more efficient, but because it confers legitimacy upon them, which then allows them to survive. Organizations look similar not as a result of a market-based rationalized process, but because "powerful forces emerge that lead them [organizations] to become similar to one another."11 DiMaggio and Powell distinguish three mechanisms of isomorphic change: coercive isomorphism (related to laws and regulations), normative isomorphism (related to education and professionalization) and mimetic isomorphism (when in a situation of uncertainty, models that are considered legitimate are imitated). A field where isomorphism takes place can be relatively unstructured and can span borders, which is the case with the organizational models discussed here. ${ }^{12}$

To explain how exactly the copying unfolded, I draw on the recently emerged literature on institutional work. This concept has grown from the shift towards agency in institutional literature. ${ }^{13}$ It emphasizes "effortful and skilful practices" directed at "creating, maintaining, and disrupting institutions." 14 According to this perspective, the creation of new organizational forms requires the agency of culturally competent individual and collective actors. ${ }^{15}$ The types of institutional work aimed at creating institutions include, for example, educating - "the educating of actors in skills and knowledge necessary to support the new institution," and advocacy - "the mobilization of political and regulatory support through direct and deliberate techniques of social suasion."16 This research is in line with studies that focus on institutional creation and the imitation of foreign organizational models in countries other than China, and that suggest the importance of local action and entrepreneurship in these processes. ${ }^{17}$ The focus on institutional work draws attention towards individual agency in institutional creation in China.

In what follows I show that the concept of institutional work, when applied to cases of transporting organizational models, is useful for explaining heterogeneity compared to original models, in this case, the heterogeneity of Chinese galleries

10 Meyer and Rowan 1977; Powell and DiMaggio 1991.

11 DiMaggio and Powell 1983.

12 Ibid.

13 DiMaggio 1988.

14 Lawrence and Suddaby 2006; Lawrence, Suddaby and Leca 2011.

15 DiMaggio 1982; 1991.

16 Lawrence and Suddaby 2006.

17 DiMaggio 1982; 1991; Khaire 2014; Lawrence and Phillips 2004; Sato, Haga and Yamada 2015. 
and auction houses. Theorists have acknowledged the unintended consequences of institutional work: according to them, "actors work to interpret, translate, transpose, edit, and recombine institutions," which leads to "unintended adaptations, mutations, and other institutional consequences." 18 Many scholars of institutional work, however, have overlooked its unintended consequences, as they have mostly focused on deliberate action and accomplishments. ${ }^{19}$ I argue that such unintended consequences explain the divergent features of the organizational forms of galleries and auction houses in China in the 1990s.

These divergences could also be explained by what the Scandinavian branch of new institutionalism called "translation" - the transformation of original models and their adaptation to the new institutional environment. Translation studies problematize the notion of isomorphism and focus on "how apparently isomorphic organizational forms become heterogeneous when implemented in practice in different organizational contexts." 20 Whereas institutional work is agentic and intentional, but may have unintended outcomes, translation refers to strategic action or to implicit messy attempts to find solutions in the new environment. ${ }^{21}$ Translation focuses on the changes of institutions in a new organizational context; institutional work does not necessarily presuppose dealing with a new context.

This article responds to Lawrence and colleagues' call to connect institutional work and translation literatures. ${ }^{22}$ By focusing on the importation of organizations to a politically and culturally different and unstructured environment, this article introduces context more forcefully into institutional work literature. Whereas institutional work literature focuses on practices on a micro level, I argue that the immediate environment of an institutional field and broader environment are useful for understanding the conditions and need for particular kinds of institutional work. Although institutional work is conceptualized by Lawrence and Suddaby as "situated," and they suggested some delineations about what kind of work "may be easier to accomplish" in what contexts, ${ }^{23}$ this literature does not aim to elaborate on how environmental factors influence institutional work. This study shows how institutional work and its outcomes are shaped by political, cultural and institutional context and how this helps explain differences in organizational models.

\section{Data and Methods}

This in-depth qualitative study focuses on the importation of two distinct organizational forms - commercial galleries and auction houses. I focus on them

18 Lawrence, Suddaby and Leca 2011.

19 Lawrence, Suddaby and Leca 2009, 10-11.

20 Boxenbaum and Strandgaard Pedersen 2009.

21 Ibid.; Czarniawska and Joerges 1996.

22 Lawrence, Suddaby and Leca 2011.

23 Lawrence and Suddaby 2006, 219, 236. 
because contemporary art organizations, closely associated with foreign art markets and consumers, are a strategic case to study the importation of models, and because the differences between the two organizational forms are illuminating. First, galleries usually have several employees, and auction houses have complex organizational structures. A gallery is a space where contemporary art exhibitions are held regularly, where sales are made at fixed prices, and artworks are primarily sourced from artists. Auction houses hold regular sales where prices are not fixed, and normally have no close ties with artists. Second, in China, galleries only work with contemporary art, whereas auction houses trade in both contemporary and traditional art, and antiques. ${ }^{24}$ Contemporary art is defined here as art that started emerging in China in the 1970s and is grounded in the Western artistic tradition, similar to the emic category "contemporary art" (dangdai $y i s h u$ 当代艺术). ${ }^{25}$ These different characteristics result in different local environments, which helps us to understand how institutional work is shaped by context and to explain divergence from original models.

This article focuses on the cases of the China Guardian auction house and the Courtyard Gallery - both private companies established during the 1990s in Beijing. Several auction houses (Duo Yun Xuan 朵云轩, China Guardian 中国 嘉德, Hanhai 瀚海) and galleries (Red Gate, ShanghART, the Courtyard Gallery) were founded in China independently of each other, but roughly simultaneously. China Guardian was chosen because it was the first joint-stock auction company specializing in Chinese art and antiques (founded in 1993, the first auction took place in 1994), and because it was the only auction house until 1996 that sold contemporary art. The Courtyard Gallery, established in 1996, was chosen because it had several managers and owners throughout the years, which allowed for good triangulation of the data.

The importance of institutional work for understanding the importation of the two organizational models was arrived at inductively after investigating materials pertaining to the emergence of the contemporary art market in China. For this, I relied on a variety of data. I consulted all the documents on the 1990s available at the Asia Art Archive (Hong Kong) in 2013, which included periodicals from the early 1990s until the present, personal correspondence, a China Guardian publication, and invitations to contemporary art events. This was supplemented by interviews and media articles published in, or written about, the 1990s art world in China retrieved from the LexisNexis database and the artron.net art market database.

To understand the intricate processes of institutional work further, in the second round of analysis, I focused on those materials that shed light on commercial galleries and auction houses, and in particular on the two chosen cases. For instance,

24 Contemporary art sold at auctions tends to be more conservative, which was especially the case in the 1990s, yet, the China Guardian auction house has traded contemporary artists like Zhang Xiaogang from the start.

25 Lü 2010. 
I familiarized myself with the book about the history of China Guardian authored by its founder. ${ }^{26}$ In addition to collecting documentary data, I conducted in-depth interviews during the period 2012-2014 with artists $(n=14)$, art dealers $(n=6)$, auction house representatives $(n=3)$, collectors $(n=4)$, art critics $(n=3)$ and other art market participants active in the Chinese art world since the 1980s and the 1990s, and/or who worked at the organizations analysed during my research. These interviews concerned the interviewees' first-hand experience with the importation of the models of auction houses and galleries and their broader experiences of China's art world in the 1980s and 1990s. Interviews typically lasted between one and two hours and were useful for interpreting and triangulating the written accounts. The interviews were recorded, transcribed and coded in Atlas.ti. I used both inductive and deductive approaches when coding documentary and interview data. Especially interviews - both published and conducted by me were useful for teasing out the dynamics of mimetic isomorphism and institutional work, and which allowed me to distinguish the types of institutional work involved, and influence of contextual factors on institutional work.

The specificities of the local environment emerged as important for explaining the need for and outcomes of institutional work. To further understand the local and foreign contexts, in addition to the data described above, I relied on in-depth interviews collected as part of the Asia Art Archive project "Materials of the Future," and on art market reports, such as TEFAF (The European Fine Art Fair) reports, China Art Market Research Reports produced by Art Market Research Centre (AMRC), affiliated with CAFA, China's top art academy, and Artprice reports. I also informed myself about the history of Chinese art, ${ }^{27}$ the art worlds, ${ }^{28}$ and the development of art markets ${ }^{29}$ elsewhere. Furthermore, this article benefited from the insights obtained during 11 months of ethnographic fieldwork carried out mostly in Beijing between 2012 and 2014, during which numerous observations, conversations with art world participants and approximately 180 interviews about the functioning of China's art market were conducted. Although these interviewees did not necessarily have first-hand experience of the Chinese galleries and auctions in the 1990s, they were familiar with the founders and/or had knowledge about galleries and auctions, including the two cases, in the 1990s and now.

\section{Local Environmental Context}

Before zooming in on the importation of the two organizational forms, it is useful to consider the local political, cultural and institutional context. This allows us to explain what institutional work had to be done, and why the models were transformed.

29 Brandellero 2015; Khaire and Wadhwani 2010. 
Art market institutions for trading in traditional Chinese art and calligraphy existed long before the 1990s: China has boasted art markets since the Song dynasty (960-1279). ${ }^{30}$ However, no commercial contemporary art galleries ${ }^{31}$ existed in pre-Mao China, only "art shops" (huadian 画店) trading in Chinese ink wash paintings, calligraphy and antiques. The first auction houses were established by foreigners as branches of English, French, Japanese and other auction houses in the late 19th century, mainly in Shanghai. The art market essentially halted during the Maoist period, although some art was produced for export within state organizations. Auctions were closed by decree in 1956. Artists became state employees who were required to "serve the people." 32 Knowledge about developments in art worlds abroad, except for the Soviet Union, was lacking.

The policy of reform and opening up, implemented since the late 1970s, resulted in emerging links with foreign art markets. Information about developments in contemporary art in Europe and the US reached China, initiating a period of artistic experimentation. ${ }^{33}$ Exhibitions of foreign artists such as Rauschenberg were organized in China, and starting from the 1990s, Chinese artists participated in Venice Biennale and other prestigious exhibitions abroad. Between the late 1970s and early 1990s, a number of Chinese artists moved to the US, Japan and other countries, where they began working with foreign galleries. Foreign organizations started engaging with China, although not yet on a regular basis. Sotheby's held a charity auction in Beijing in 1988, which remained a oneoff occurrence. Foreign dealers such as Johnson Chang and Yukihito Tabata visited China and began to take an interest in Chinese artists.

These emerging links with foreign art markets indicated China's entrance into the transnational art market field. ${ }^{34}$ Nevertheless, interaction and the flow of information were limited, and the political, cultural and institutional environment to which the foreign models were introduced in China, was different. As I show later in this article, these differences shaped institutional work and led to unintended consequences.

In contrast with established markets abroad, in early 1990s China, the contemporary art market was not yet institutionalized. No stable spaces for selling, and few spaces for exhibiting experimental contemporary art existed. ${ }^{35}$ Contemporary art was sold sporadically and directly instead of through organizations. Exhibitions were held in the apartments of diplomats and other foreigners, in artists' homes or studios, in temples, parks, hotels or basements. ${ }^{36}$ The exhibited works were usually for sale, but few were sold. Some exhibitions were held for an

30 Clunas 2009

31 cf. Velthuis 2005.

32 Sullivan 1996.

33 Wu 2014.

34 DiMaggio and Powell 1983; Meyer et al. 1997; Velthuis and Baia Curioni 2015.

35 DeBevoise 2014; Wu and Wang 2010.

36 Even though it says "gallery" on some of the exhibition invitations from the 1990s, such as Tao Gallery or Wins Gallery, they were actually framing or painting shops, or temporary exhibition spaces that were called a gallery but did not have a commercial gallery operation or structure. 
afternoon, and they mostly only attracted artists and a few foreigners. Karen Smith, who ran the Courtyard Gallery during its first year, organized two such exhibitions in her apartment. She explained:

...a lot of people did it at the time, and it was a social occasion, because we knew lots of foreign people in different kind of fields, and artists who were in need of money or in need of support. So, you know, you basically just did a Saturday afternoon, and people would come over for a drink or maybe a beer or something and maybe they bought a few prints...

Unlike in Europe and the US, the infrastructure of contemporary art museums, art fairs, biennales, and a contemporary art press, was absent. There were no training programmes in contemporary art management, art history or criticism. According to the art critics and artists whom I interviewed, most artists had a vague idea how to price their work or how galleries or auction houses work exactly. Artists outside the official art system had few opportunities to exhibit at official venues. No governmental support for contemporary art, such as prizes or fellowships, existed. Although potential Chinese buyers might have been used to museums of traditional art and versed in Chinese art and antiques, contemporary art was unfamiliar to them. As my interviewee, who was active in the art world at the time, told me, contemporary art was "very very difficult to find." This lack of familiarity with contemporary art among the public and cautious attitude of the government was particularly consequential for commercial galleries that dealt only in contemporary art, as opposed to auctions that, besides contemporary art, primarily dealt with traditional art and antiques.

At the same time, the policy environment for setting up art market organizations was no longer overtly hostile. The government was gradually introducing markets for cultural goods. Since the 1980s and especially since the 1990s, the central government has promoted trade in cultural products or "culture markets." As Xinhua news agency reported, "the green light was given by the government which is keen to boost both the cultural and the commercial sectors to meet the market economy." 37 The situation was especially favourable for auctions. The prohibitions on auctions were relaxed in the 1980s. Art auctions (not organizations) were legalized again in 1991 in an attempt to curb the illegal trade in cultural relics and regulate the market, to control what was going out of the country and collect taxes on it. The government also planned to set up auction houses in the long run. ${ }^{38} \mathrm{~A}$ few experiments with art auction sales occurred across China from 1992 onwards. Some of the first auctions were organized by government-related organizations and/or were sanctioned by local authorities. In contrast, throughout the 1990s, no regulations about commercial galleries existed. The authorities were cautious with, and in some cases simply uninterested in galleries' contemporary art. Overall, the market-focused regulations since the late 1970s, and particularly since 1992, made the establishment of art market 
organizations possible, but the first organizations were not established top-down by the authorities.

Initially, foreign auction houses and commercial galleries did not set up shop in China. Neither Sotheby's nor Christie's were permitted to hold regular auctions in mainland China until 2012-2013, although they had held auctions in Hong Kong since 1973 and 1986, respectively, and had opened representative offices in China in 1994. Foreign galleries, for example, from Taiwan and Japan, worried about the lack of local collectors and the perceived state restrictions on art. As I show below, the first auction houses and commercial galleries were indigenous, rather than branches of foreign organizations.

\section{Who Conducted Institutional Work and Why: Institutional Entrepreneurs and Mimetic Isomorphism}

Before elaborating on the intricacies of the institutional work involved in the establishment of these organizations, I show who conducted institutional work and why they introduced these particular models.

The institutional work of implementing the two organizational forms in China was conducted by institutional entrepreneurs, who were groups of locally based individuals. ${ }^{39}$ China Guardian was founded by Chen Dongsheng 陈东升 and his team. Chen, then 36, did not (yet) occupy a central position in the nascent art field, but he had government and business connections due to his work as researcher at the Ministry of Foreign Trade and Economic Cooperation. He assembled a team, some of them university friends rather than art experts, many in their thirties. Some were working in the state cultural sector, but not all; the director of the oil painting department, for example, had no prior knowledge of art. For traditional art, the team consulted art experts from traditional art organizations, who helped, among other things, with consignments and appraisals. For business matters, they solicited the help of, among others, Chen's friend from the market department of the Ministry of Culture. Early on, Chen invited Wang Yannan 王雁南, daughter of former prime minister and general secretary of the Communist Party, Zhao Ziyang 赵紫阳, who oversaw the 1980s economic reforms, to join the team. My interviews indicated that she was highly respected in art circles because of her father's solidarity with students during the 1989 Tiananmen 天安门 protests. Wang had overseas experience as she had studied hotel management in the US, spoke fluent English, and was deputy general manager at Beijing's five-star Great Wall Sheraton Hotel (China Guardian later set up office there).

Whereas foreign nationals only acted as outside consultants for China Guardian, the early galleries were mostly established by foreigners. The Courtyard Gallery was established by American lawyer-entrepreneur, Handel 
Lee, and other investors. ${ }^{40}$ Two of the other early galleries, Red Gate and ShanghART, were also founded by foreigners based in China, Brian Wallace and Lorenz Helbling. Foreigners had prior knowledge of the gallery model, easier access to buyers, and an interest in contemporary art.

Why did they establish these particular organizational forms? In both cases the institutional entrepreneurs were pulled towards the Western models. They imitated the international models not because of efficiency - the next section shows that they were hardly efficient in the local context - but because in the highly unstructured and uncertain environment of reform-era China the entrepreneurs perceived them to be "legitimate or successful." 41 This suggests a process of "mimetic isomorphism" that took place in the transnational art field, in which the models were brought to China from the relatively established art markets abroad (Europe, the US and Hong Kong).

Chen clearly perceived the foreign auction houses as legitimate. He first encountered auctions in Xinwen Lianbo 新闻联播 television programmes featuring Sotheby's and Christie's, and was fascinated:

...in a classical building, an elegant auctioneer overlooking men and women in the audience, rising paddles, mysterious phone calls, exchanging a word or two here and there, all of it so elegant, so far away, but so impressive. ${ }^{42}$

Later, his friends showed him a newspaper article, which lamented: "with its 5,000 years of history, China has multiple cultural treasures and rich heritage, but not a single influential art auction company." 43 This, combined with the strong impression from TV programmes, made him decide to establish an auction house.

Chen was well aware of the effect his efforts would have on the nascent market, which could be interpreted as pointing towards efficiency and away from mimetic isomorphism as the reason for adopting the model. However, the data presented below indicate mimetic isomorphism. Both Chen and Wang had virtually no knowledge of the auction business at the time. They "had no idea where to get lots and how to auction." 44 They had no arts background and were outsiders in the art world. "To innovate is to be the first to copy," Chen is often quoted in Chinese business circles as saying. ${ }^{45}$ In a situation of lack of knowledge and uncertainty, Chen and his team imitated the internationally successful model of Sotheby's, which had long been active in Hong Kong. According to an interview with Chen, "from packaging, pricing, catalogues and screens to expert and credit systems - the Guardian imitated it all."46 Westney wrote that those who copy often lack first-hand knowledge of the models, which results in divergence. ${ }^{47}$ Chen's team tried to acquire such knowledge. They consulted Sotheby's experts

40 The Courtyard Gallery closed; one of its founders, Meg Maggio, now owns Pékin Fine Arts gallery.

41 Beckert 2010; DiMaggio and Powell 1983, 152.

42 Yang 2013.

43 Chen 2014.

44 Yang 2013.

45 Ibid.

46 Ibid.

47 Westney 1987. 
in Beijing and often went to Hong Kong to observe auctions and study organizational set-up and practices. Chen selected his first auctioneer, Gao Deming 高德明, who would later become China Guardian's top auctioneer, based on his impressions of the foreign auctions he saw on Xinwen Lianbo. Later, the Irish Times described Gao as follows:

Typically dressed for work in bow tie and stiff wing tip collar, he models himself on Julian Thompson, the smooth and composed senior auctioneer at Sotheby's. ${ }^{48}$

Available photos indicate that the auction sale was set up similarly to Europe and the US, with rows of bidders and spectators, and an auctioneer at the front. In many ways, China Guardian was isomorphic. Imitation of the legitimate successful model by the founders of China Guardian in a situation of uncertainty points to mimetic isomorphism.

Founders of the first contemporary art galleries also viewed the Western model as legitimate. Similar to the China Guardian team, they could not be considered "professionals," 49 but they were familiar with the Western gallery system. They oriented themselves towards practices common in Europe and the US. In interviews, they claimed they had been "build[ing] a platform" rather than operating "like a shop." Similar to European and US galleries, they organized regular shows, and their space resembled a white cube gallery. ${ }^{50}$ According to Meg Maggio, an American investor and later director of the gallery, who had been living in Hong Kong and Beijing for a number of years, the Courtyard was:

...basically introducing a new Western model. It wasn't that it was a cultural desert. No way. They have their own way of exhibiting art. Their own way of using exhibition space. We were introducing a Western way of exhibiting art.

Although they were aware of the dearth of galleries in Beijing, the Courtyard did not aim to strategically build an art market or to make a substantial profit. As Maggio said in an interview: ${ }^{51}$ "we were working as lawyers and we thought it would be fun." This suggests that copying was not driven by efficiency.

The gallery was not a serious business venture, but something investors did on the side. It was located in the centre of Beijing, at the moat of the Forbidden City, in the basement of an upscale restaurant. Some of the investors were more interested in the restaurant than the gallery. Others were more interested in art than the art business. Maggio, 36 at the time, and who had collected art since the 1980 s, was already involved in the contemporary art scene. For her, the gallery was more about interaction with art and artists, about an adventure:

It was more like making beautiful exhibitions and sometimes making catalogues. So that was more exciting than whether you'd sell the work or not. Yeah, we'd sell a few pieces and we'd pay for everything. But we didn't think about it almost. There was a price list, but you

48 O’Clery 1997.

49 Lawrence, Leca and Zilber 2013. Other first gallerists had no experience either.

50 Other galleries established in the 1990s were run informally from lobbies of five-star hotels and from a Ming-dynasty tower, all highly unusual arrangements. Among the reasons were restrictions on foreigners, who could not register a company in their name until the 2000s.

51 Interview with Meg Maggio, July 2014. 
didn't have high expectations for sales. You know, you were kind of like, maybe someone might buy something.

Karen Smith, a British national active in Beijing's contemporary art circles, who was initially invited to run the gallery, recounted in an interview ${ }^{52}$ that she saw her purpose in organizing artistic activities, but "didn't want to have anything to do with developing the kind of market." The Courtyard, like Red Gate and other early galleries, grew out of friendships with artists, and was little concerned with efficiency. In fact, because of the uncertainty of the economic and cultural climate during the 1990s in China, it was hard for the founders to predict how efficient the model would be.

Similar to China Guardian, my interviews with gallerists indicate that they did not know how to organize a gallery or what the reaction to the new organizational model would be. Neither Smith nor Maggio, who, after about a year, resigned from her job as a lawyer and took over gallery management from Smith, had experience with running a gallery. In a situation of uncertainty, they turned to the foreign model that they considered legitimate. Combined with a lack of strategy or attention to efficiency, this suggests that institutional entrepreneurs imitated the foreign gallery model in a mimetic isomorphic way.

\section{Institutional Work as Shaped by the Local Context}

Implementing the two organizational forms in China required institutional work. Mimetic isomorphism implies adopting a model perceived as successful in a situation of uncertainty and ambiguity. ${ }^{53}$ In our cases, the organizational forms were viewed as desirable by institutional entrepreneurs, and by foreigners, and were meant to confer legitimacy. However, at the moment of their introduction, they were not yet taken for granted or considered successful by most local people in China, who were not part of the transnational contemporary art field. Neither the authorities, nor most local artists and potential buyers, were even aware of these organizational forms, let alone related practices. Apart from some artists, entrepreneurs could not simply appeal to the organizations' legitimacy (as in isomorphism), but to a certain extent needed to build it. They also needed to conduct other types of institutional work to establish the organizations. The aim of this section is not to provide an exhaustive account of all institutional work conducted. Instead, below I show how the local political, cultural and institutional context, which was distinct from the original context and which partly differed for galleries and auction houses, shaped what institutional work had to be done.

Both auction and gallery entrepreneurs engaged in the type of institutional work that Lawrence and Suddaby call "educating." 54 They educated artists, 
(potential) buyers, auctioneers and others in at least two ways. First, they had to educate them about contemporary art. According to Chen, at China Guardian, oil paintings initially sold for low prices or did not sell at all. ${ }^{55}$ They had to be put in the hallway during the auction preview, where everyone would pass them and where the department manager would latch on to visitors and try to convince them of their value. This was an even more acute problem for galleries, which only dealt in contemporary art. This made it difficult for some galleries to survive. A member of the initial China Guardian team, Gan Xuejun 甘学军, unsuccessfully ran a gallery for several years in the late 1990s and ended up opening his own auction house. As he put it:

It was difficult. I lost money, lost, because we were doing contemporary art. Nobody cared for Zhang Xiaogang 张晓刚 or Yue Minjun 岳敏君. We couldn't sell Mao Yan 毛焰. ${ }^{56}$ [...] So I went back to the auction business. ${ }^{57}$

At the Courtyard Gallery, according to Smith, at least in the first years, artworks either did not get sold or got sold to acquaintances as a favour. Interviews indicate that early galleries relied on foreign buyers, with the first local buyers appearing only in the early 2000s. Yet, few foreigners were interested in contemporary art, and some, like one of the main collectors at the time, Uli Sigg, preferred to buy directly from artists. One way to attract potential buyers was through the restaurant.

Second, although some artists knew about the international models of galleries and auction houses, and found them attractive, entrepreneurs needed to educate local artists, auctioneers, and even investors, about how the models should work. China Guardian rigorously trained its employees. Smith explained to investors that she needed to establish the gallery's reputation before the sales could be realized. Gallerists had to spell out for artists how collaborations should function. "We are not a pawnshop," is something Maggio says she had to constantly repeat to artists:

You don't place your objects here and walk away and wait for the day I call you and give you money. [...] This is a long-term relationship. ${ }^{58}$

The local context made certain types of institutional work unnecessary. For example, in both cases the institutional work of "changing normative associations" - "re-making the connections between sets of practices and the moral and cultural foundations for those practices" - did not have to be done. ${ }^{59}$ In the environment of economic reforms, artists were excited by a new possibility to make money, and buyers were thrilled to participate in an overt market activity, such as an auction. My interviews with artists, art dealers and others indicate that artists did not take the organizational forms for granted, but they were

55 Chen 2014.

56 Zhang Xiaogang, Yue Minjun and Mao Yan are currently among the top Chinese artists.

57 Interview with Gan Xuejun, manager at China Guardian, July 2014.

58 Interview, Meg Maggio.

59 Lawrence and Suddaby 2006, 224. 
enthusiastic. For artists, it was a long-awaited opportunity to exhibit and sell their work, to gain visibility. Artists did not require much persuasion to work with new organizations that they quickly perceived as professional. Artists were "super curious" about the new gallery model, as Maggio put it. According to an artist who worked with the Courtyard Gallery in the 1990s:

Everyone wanted to cooperate with a gallery. Galleries were a new thing, they had just entered China. We artists thought, what is a gallery, after all? If you work with a gallery, what would be the results and the future? We had no idea. But if you could have an exhibition so that many people would see your work, we were very happy.

Similarly, Smith said that artists "were really excited about that [auctions] in a way, because it was something that seemed solid, that had a real kind of foundation." 60 Also, for (potential) buyers, auctions were fascinating. "Auctions are a novelty for the Chinese, who relate them to ordinary things like car number plates and items seized by the customs department," wrote Agence France Press in $1994 .{ }^{61}$ Auctions quickly caught on: a steep admission fee even had to be charged, for example, at China Guardian's 1995 spring auction, to limit the audience, as "[d]rawn by [...] the excitement of seeing vast sums of money change hands, local Chinese flocked to the event."62

Alongside these similarities, other types of institutional work differed for gallery and auction house, as they are differently positioned regarding the government. In China, at least tacit approval by the authorities was required for operation, so official legitimation was necessary. This was especially crucial for the auction house. The China Guardian entrepreneurs engaged in a form of institutional work that Lawrence and Suddaby call "advocacy": they needed to obtain political and regulatory support. ${ }^{63}$ It was a "political" "institutionalization project" related to market-building. ${ }^{64}$ Despite economic liberalization and local authorities' auction experiments, China Guardian needed official approval. When applying for licences, they ran into problems: the officials at the State Administration of Cultural Heritage worried that granting a licence to auction cultural relics would lead to grave robberies. Chen and his associates needed to use their networks to lobby for the desired outcomes. To legitimize auction houses, which are large conspicuous organizations, entrepreneurs needed political capital. They sought the support of official arts organizations and their leaders. Chen relied on his network accumulated while working as a civil servant at a research institute. Wang Yannan's high profile was also useful, even though she did not use her father's surname, and did not seem to flaunt her high cadre family background. Advocacy was only necessary in the beginning. The auction house was quickly legitimated when a number of Party and government leaders attended the first auction. The central television programme, Oriental

60 Interview, Karen Smith.

61 Leu 1994.

62 Dewar 1995.

63 Lawrence and Suddaby 2006.

64 DiMaggio 1988, 13. 
Horizon, praised it highly, predicting that Beijing would become an auction capital, on a par with New York and London. ${ }^{65}$ The China Association of Auctioneers was established in 1995, and an auction law was issued in 1996. Regulations for professional certification for auctioneers took effect in 1997. Thus, within several years the significance of China Guardian's first auction was recognized and legitimized by the authorities.

In contrast, the galleries did not engage in "advocacy." As foreigners and outsiders to pre-existing traditional art structures, gallerists lacked the political capital and other resources for advocacy. Also, there was little need to advocate. Dealers active at the time told me that commercial galleries experienced neither support nor serious restrictions. As small marginal inconspicuous organizations dealing with contemporary art, galleries were of little interest to the authorities, and there was tacit approval of local police or cadres, according to Maggio and other interviewees. Wallace, who ran Red Gate gallery, told me that the authorities would come by, "but then they'd just go away, really, they didn't cause us too much trouble." They could overcome regulatory obstacles, such as restrictions on economic activities of foreign nationals and companies, without advocacy, for example, by collaborating with Chinese nationals or establishing galleries in hotels.

In sum, the institutional work was shaped by the local political, cultural and institutional context. A lack of knowledge of contemporary art and of workings of organizations, official requirements and attitudes towards market organizations and towards contemporary art dictated what institutional work local actors had to conduct. In these two cases in 1990s China, entrepreneurs had to educate local actors about contemporary art and the workings of organizations and to have at least tacit support of the authorities. Auction houses engaged in more "advocacy," while contemporary art "education" was more crucial for galleries, since auction houses and galleries and their founders were differently positioned with relation to these contextual factors. The atmosphere of embracing economic reforms rendered the institutional work of "changing normative associations" unnecessary.

\section{Transformations of Foreign Models as Unintended Consequences of Institutional Work}

Attempts at isomorphism did not result in complete mimesis; innovation accompanied imitation. ${ }^{66}$ Chinese organizations functioned differently from the originals. For example, China Guardian received artworks for auction directly from artists, unmediated by art dealers, which is considered illegitimate internationally. ${ }^{67}$ The Courtyard Gallery did not promote artists at not-for-profit institutions, as galleries are expected to do, and had an extraordinary business model (it was partly supported by profits from the restaurant). The relationship between galleries and

67 cf. Kharchenkova and Velthuis 2018. 
auction houses was also divergent. For instance, contrary to international conventions, Chinese galleries were not initially buying or selling art at auction.

My interview and archival data suggest that the bricolage of pre-existing socialist and new structures, which is often used to explain Chinese institutional divergencies, does not account well for modifications of these two contemporary art organizations. China Guardian drew on pre-existing institutions and relationships embedded in the old structures and in the traditional art circuit, for example, to obtain traditional art lots at cultural relics stores. However, China Guardian could not readily rely on pre-existing structures where it came to contemporary art, because no old organizational template existed for contemporary art commerce. Similarly, the Courtyard Gallery did not draw on pre-existing structures. The differences also cannot be explained by a "mimicry" type of institutional work - an intentional layering of old and new to make the new models understandable and point to shortcomings of the old practices. ${ }^{68}$ Organizational forms were attractive due to their foreign novel character, and both the Courtyard Gallery and China Guardian emphasized it. ${ }^{69}$ Additionally, early galleries primarily dealt with foreigners and artists active outside of the official system, so "mimicry" would not be useful.

Rather, my data suggest that the differences are largely due to what Lawrence and colleagues call "unintended consequences" of institutional work: institutional work may create institutions "very different from those originally conceived of by the actors involved."70 This, in turn, had to do with the fact that the local environment to which the models were copied was not only politically, culturally and institutionally different, but also emergent and unstructured. It lacked contemporary art infrastructure, professionalization, consumers, and the new organizations had different meanings for local actors - artists, potential buyers, the authorities - compared to their original context. As a result, the organizations could not operate in line with the original models. My data clearly indicate entrepreneurs' objective to copy organizations, but the Chinese organizations turned out to be different, therefore I conceptualize this as the "unintended consequences" of institutional work.

For example, the auction house representatives approached artists directly with a view to auctioning their works, because of a lack of galleries and collectors at the time. As no market-related conventions, which forbid artists to collaborate with auctions, existed, artists were eager, resulting in a different, more direct, relationship. As a China Guardian manager explained:

A lot of people participated out of curiosity. [...] auctions brought sales, but they also published artworks in the catalogue, published books and made exhibitions, so that many collectors would see them. At the time there was no other way, there were no galleries. ${ }^{71}$

68 Lawrence and Suddaby 2006.

69 Chen 2014, 59; interview with Maggio.

70 Lawrence, Suddaby and Leca 2009, 10-11.

71 Interview with China Guardian manager, July 2014. 
For the Courtyard Gallery, the international model of having a limited stable of artists that galleries promote long-term, and where works by such artists would only be sold through the gallery, did not work well, according to Maggio. The gallerists could not promote artists at museums, because no contemporary art museums to consecrate artists existed. The priority in an environment where contemporary art received no support was more immediate: to organize exhibitions and to guarantee a living to the artists. If they had sold art before, artists dealt directly with buyers, so they did not know what exactly to expect of a gallery in terms of cooperation either. The Courtyard Gallery was supported by the restaurant due to a lack of contemporary art buyers.

Because the field was nascent and not yet professionalized, it lacked scripts and institutionalized procedures on how to operate a gallery or an auction house. This was exacerbated by the overall uncertainty and rapid changes of the reform period. Sometimes adjustments were spontaneous rather than planned and resulted from a lack of experience and clarity about how galleries and auction houses should operate locally. According to my respondents, gallerists were learning by doing, and disagreed on how to run the gallery, especially early on. According to Maggio, initially they:

...had no record keeping, they didn't keep accounts, things were flying out the window, they were working with other galleries from our gallery, it was a mess. ${ }^{72}$

The China Guardian team did not know how to write a feasibility report, or how the first auction would play out. All this highlights the uncertain character of institutional work, resulting in unintended consequences and transformations of original models.

These organizational differences can be explained by "translation" of models to the Chinese context, which refers to modifications of institutions in a new organizational context. ${ }^{73}$ However, they can also be explained by unintended consequences of institutional work. Whereas translation refers to implicit or strategic search for solutions in the new environment, unintended consequences of institutional work emphasize (partial) failure: a different, unintended outcome of creating of organizational forms, or in this case, of bringing isomorphic organizational forms to China.

\section{Conclusions}

This article has detailed micro-level mechanisms of importation of two organizational forms. This was a multi-level process with mimetic isomorphism taking place on the transnational level (between mature markets abroad and a nascent market in China), and institutional work taking place mostly locally. Although isomorphism is usually understood as emphasizing structure, institutional entrepreneurship and work underscore agency, and unintended consequences of

73 Czarniawska and Joerges 1996. 
institutional work presuppose a lack of deliberate action; a combination of these concepts is necessary to make sense of how the models were imported and transformed.

The contributions of this article are twofold. First, this study contributes to China scholarship, as it applied the concept of institutional work to China. It conceptualized economic reforms since the 1970s and especially the 1990s as a condition for institutional work of creating market institutions in China. One advantage of this approach is that it offers an alternative explanation for institutional differences in reform-era China. Although path dependence and a bricolage of elements of old and new institutions were relevant for traditional art and antiques, I have argued that concerning contemporary art, modifications of models can be best explained by the unintended consequences of institutional work in an unstructured environment. This analysis underscores intentionality, but also the messiness of institutional creation. The role of unintended consequences of institutional work in creating divergences in other industries and markets in China, and the concrete dynamics associated with them, is a welcome avenue of future research.

Another important advantage of this micro-level approach is that it highlights individual agency in China's organization-building. ${ }^{74}$ This study revealed the role of foreign nationals, which, unlike the role of foreign investment and joint ventures, has been neglected in sociological literature on China's market development. Their successful contributions were due to their cultural competence among Western-oriented artists and foreigners dominating this nascent market of contemporary art, as well as to the fact that they ran relatively small inconspicuous organizations. This study thus calls for more attention to micro-level agency in studies of creation, maintenance and disruption of Chinese organizations.

Second, this study contributes to institutional work literature by highlighting how contextual factors (1) shaped institutional work and (2) led to unintended consequences of institutional work. This helps address the current academic interest in differences in institutionalization processes. ${ }^{75}$ Which contextual factors beget which types of institutional work should be investigated further on the empirical material in China and beyond. In addition, this article suggests further studying the role of unexpected consequences of institutional work in the development of organizations and markets. Unintended consequences seem especially likely to occur in an unstructured environment; however, in what other kinds of environments unintended consequences can be expected should be investigated further.

Finally, this article suggests further applying institutional theory to China, which, as I have shown, has analytic uses for the study of Chinese society. Emphasizing the structure, the institutional approach also underscores the

75 Lawrence, Suddaby and Leca 2011. 
creative agency. With its attention to the local rather than the universal, and to the symbolic and cultural rather than rational dimensions of institutional diffusion, its advantage is that it allows us to trace the intricate processes of building, maintaining and disrupting institutions in post-Mao China.

\title{
Acknowledgements
}

I am grateful to Olav Velthuis, Giselinde Kuipers, Alex van Venrooij and Frank Pieke for their helpful comments on the earlier versions of this manuscript and for their continuous encouragement and support. Drafts of this article were presented at the conferences of the European Sociological Association, American Sociological Association, European Group for Organizational Studies and at the "Inverting Globalization" conference at the University of Amsterdam. I thank their participants, as well as anonymous reviewers at the China Quarterly, for their valuable suggestions. This work was part of the research project "The globalization of high culture: how markets for contemporary art develop in Brazil, Russia, India and China," which was financed by a VIDI grant of the Netherlands Organisation for Scientific Research (NWO). NWO's support is gratefully acknowledged.

\section{Biographical note}

Svetlana KHARCHENKOVA is lecturer of sociology of modern China at Leiden University. Her research bridges contemporary China studies and economic and cultural sociology. In particular, she studies Chinese creative industries and cultural markets in a global perspective. She defended her $\mathrm{PhD}$ dissertation White Cubes in China: A Sociological Study of China's Emerging Market for Contemporary Art at the University of Amsterdam in 2017. Her research of the development of the Chinese contemporary art market has been published, among others, in Socio-Economic Review and Poetics: Journal of Empirical Research on Culture, the Media and the Arts.

\begin{abstract}
摘要：这篇文章提出了一个对在中国运行的机构的制度性差异的新解释。 它集中分析当代艺术品市场的两种主要机构形式（商业画廊和拍卖公司） 如何于 90 年代在中国首次成立。基于对档案以及采访数据的分析，本文认 为上述两种机构形式是因为模仿同形而被介绍到中国的, 另外, 它们与国 外当代艺术品市场机构模式之间的差异是制度工作的非预期结果。本文强 调了个人能动性（包括外国人）在中国的机构建立过程中起到的作用。本 文的结论还对制度理论有一定的影响: 文中展示了中国的政治、文化和制 度环境是如何决定哪些制度工作是必须的, 以及此环境如何导致制度工作 的非预期结果。
\end{abstract}

关键词: 经济社会学; 模仿同形, 制度工作; 机构建立过程; 艺术品市场; 画 廊, 拍卖公司; 当代艺术; 中国 


\section{References}

Beckert, Jens. 2010. "Institutional isomorphism revisited: convergence and divergence in institutional change." Sociological Theory 28(2), 150-166.

Boxenbaum, Eva, and Jesper Strandgaard Pedersen. 2009. "Scandinavian institutionalism - a case of institutional work." In Thomas Lawrence, Roy Suddaby and Bernard Leca (eds.), Institutional Work: Actors and Agency in Institutional Studies of Organizations. Cambridge: Cambridge University Press, 178-204.

Brandellero, Amanda. 2015. "The emergence of a market for art in Brazil." In Olav Velthuis and Stefano Baia Curioni (eds.), Cosmopolitan Canvases: The Globalization of Markets for Contemporary Art. Oxford: Oxford University Press, 215-237.

Chen, Dongsheng. 2014. Yichuidingyin: wo yu Jiade ershi nian (Fixing the Tune with a Single Hammer Blow: My Twenty Years with the Guardian). Beijing: Shenghuo dushu, xinzhi sanlian shudian.

Clunas, Craig. 2009. Art in China (Oxford History of Art). Oxford: Oxford University Press.

Czarniawska, Barbara, and Bernward Joerges. 1996. "Travels of ideas." In Czarniawska, Barbara, and Guje Sévon (eds.), Translating Organizational Change. Berlin: Walter de Gruyter, 13-48.

DeBevoise, Jane. 2014. Between State and Market: Chinese Contemporary Art in the Post-Mao Era. Leiden: Brill.

Dewar, Susan. 1995. "Report from Beijing." Orientations October, 94-97.

DiMaggio, Paul. 1982. "Cultural entrepreneurship in nineteenth-century Boston: the creation of an organizational base for high culture in America." Media, Culture and Society 4, 33-50.

DiMaggio, Paul J., and Walter W. Powell. 1983. "The iron cage revisited: institutional isomorphism and collective rationality in organizational fields." American Sociological Review 48(2), 147-160.

DiMaggio, Paul. 1988. "Interest and agency in institutional theory." In Lynne G. Zucker (ed.), Institutional Patterns and Organizations: Culture and Environment. Cambridge, MA: Ballinger, 3-21.

DiMaggio, Paul J. 1991. "Constructing an organizational field as a professional project: U.S. art museums, 1920-1940." In Walter W. Powell and Paul J. DiMaggio (eds.), The New Institutionalism in Organizational Analysis. Chicago, IL: University of Chicago Press, 267-292.

Fligstein, Neil. 1996. "The economic sociology of the transitions from socialism." American Journal of Sociology 101(4), 1074-81.

Guthrie, Doug. 1999. Dragon in a Three-Piece Suit: The Emergence of Capitalism in China. Princeton: Princeton University Press.

Khaire, Mukti. 2014. "Fashioning an industry: socio-cognitive processes in the construction of worth of a new industry." Organization Studies 35(1), 41-74.

Khaire, Mukti, and R. Daniel Wadhwani. 2010. "Changing landscapes: the construction of meaning and value in a new market category - modern Indian art." Academy of Management Journal 53(6), 1281-1304.

Kharchenkova, Svetlana, and Olav Velthuis. 2018. "How to become a judgment device: valuation practices and the role of auctions in the emerging Chinese art market." Socio-Economic Review 16(3), 459-477.

Lawrence, Thomas B., and Nelson Phillips. 2004. "From Moby Dick to Free Willy: macro-cultural discourse and institutional entrepreneurship in emerging institutional fields." Organization 11(5), 689-711.

Lawrence, Thomas B., and Roy Suddaby. 2006. "Institutions and institutional work." In Stewart R. Clegg, Cynthia Hardy, Thomas B. Lawrence and Walter R. Nord (eds.), Handbook of Organizational Studies. London: Sage, 215-254.

Lawrence, Thomas, Roy Suddaby and Bernard Leca. 2009. Institutional Work: Actors and Agency in Institutional Studies of Organizations. Cambridge: Cambridge University Press.

Lawrence, Thomas, Roy Suddaby and Bernard Leca. 2011. "Institutional work: refocusing institutional studies of organization." Journal of Management Inquiry 20(1), 52-8.

Lawrence, Thomas B., Bernard Leca and Tammar B. Zilber. 2013. "Institutional work: current research, new directions and overlooked issues." Organization Studies 34(8), 1023-33. 
Leu, Siew Ying. 1994. "Auctioneers' hammer stirs Chinese art collectors.” Agence France-Presse, 30 October.

Lü, Peng. 2010. A History of Art in 20th Century China. Milan: Charta.

Meyer, John W., and Brian Rowan. 1977. "Institutionalized organizations: formal structure as myth and ceremony." The American Journal of Sociology 83(2), 340-363.

Meyer, John W., John Boli, George M. Thomas and Francisco O. Ramirez. 1997. "World-society and the nation-state." American Journal of Sociology 103(1), 144-181.

Nee, Victor. 1989. "A theory of market transition: from redistribution to markets in state socialism." American Sociological Review 54(5), 663-81.

Nee, Victor. 1992. "Organizational dynamics of market transition: hybrid forms, property rights, and mixed economy in China." Administrative Science Quarterly 37(1), 1-27.

Nee, Victor, and Sonja Opper. 2012. Capitalism from Below: Markets and Institutional Change in China. Cambridge, MA: Harvard University Press.

O'Clery, Conor. 1997. "Revolutionary exotica among bargains in the city planned by 'Chinese' Gordon." The Irish Times, 15 April, 13.

Oi, Jean C. 1995. "The role of the local state in China's transitional economy." The China Quarterly 144, 1132-49.

Pieke, Frank. N. 2016. Knowing China: A Twenty-First Century Guide. Cambridge: Cambridge University Press.

Powell, Walter W., and Paul J. DiMaggio. 1991. The New Institutionalism in Organizational Analysis. Chicago, IL: University of Chicago Press.

Sato, Ikuya, Manabu Haga and Mamoru Yamada. 2015. "Lost and gained in translation: the role of the 'American model' in the institution-building of a Japanese university press." Cultural Sociology 9(3), 347-363.

Stark, David. 1992. "Path dependence and privatization strategies in Eastern Europe." Eastern European Politics and Societies 6, 17-54.

Stark, David. 1996. "Recombinant property in East European capitalism." American Journal of Sociology 101, 993-1027.

Stark, David, and László Bruszt. 1998. Postsocialist Pathways: Transforming Politics and Property in East Central Europe. Cambridge: Cambridge University Press.

Sullivan, Michael. 1996. Art and Artists of Twentieth-Century China. Berkeley: University of California Press.

Szelenyi, Ivan, and Eric Kostello. 1996. “The market transition debate: toward a synthesis?” American Journal of Sociology 101(4), 1082-96.

Velthuis, Olav. 2005. Talking Prices: Symbolic Meanings of Prices on the Market for Contemporary Art. Princeton, NJ: Princeton University Press.

Velthuis, Olav, and Stefano Baia Curioni. 2015. "Introduction: making markets global." In Olav Velthuis and Stefano Baia Curioni (eds.), Cosmopolitan Canvases: The Globalization of Markets for Contemporary Art. Oxford: Oxford University Press, 1-30.

Walder, Andrew. 1995. "Local governments as industrial firms: an organizational analysis of China's transitional economy." American Journal of Sociology 101, 263-301.

Westney, D. Eleanor. 1987. Imitation and Innovation: The Transfer of Western Organizational Patterns to Meiji Japan. Cambridge: Harvard University Press.

Wu, Hung. 2014. Contemporary Chinese Art: A History (1970s-2000s). London: Thames and Hudson.

Wu, Hung, and Peggy Wang (eds.). 2010. Contemporary Chinese Art: Primary Documents (MoMA Primary Documents). Durham, NC: Duke University Press.

Yang, Xue. 2013. "Chen Dongsheng: zuoshou yishu, youshou jinrong" (Chen Dongsheng: art in the left hand, finance in the right hand), Qiye guanchajia (Enterprise Observer), April. 